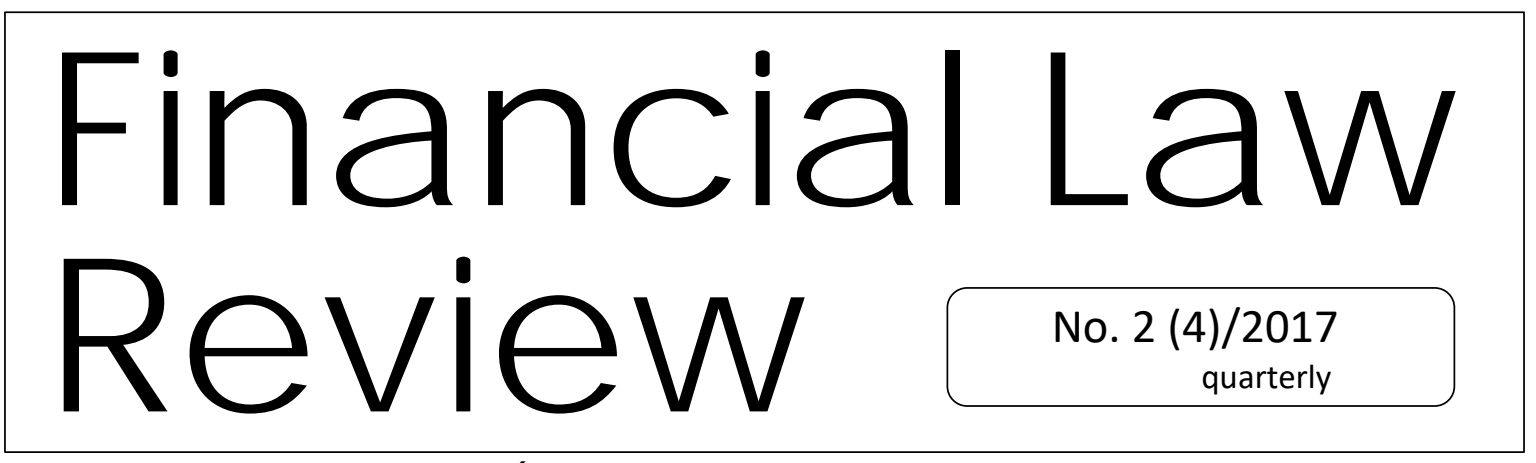

UNIVERSITY OF GDAŃSK • FACULTY OF LAW AND ADMINISTRATION http://www.ejoumals.eu • http://c za so pisma.bg.ug.edu.pl

\title{
CURRENT SYSTEM OF FUNDING OF LOCAL SELF-GOVERNMENT IN SLOVAKIA AND ITS CHALLENGES ${ }^{1}$ Anna Románova", Karolina Červena"
}

\section{Abstract}

This contribution provides for the picture of revenue sources of municipalities as the basis of local self-government in Slovak Republic with respect to the state of the art and recent changes in legislation relevant thereto, as well as pending proposals for future changes towards increasing the financial independence of local self-government. Authors will analyse the above mentioned issues in order to evaluate the overall situation and confirm or disprove the hypothesis that current own revenue resources of local self-

\footnotetext{
1 The article is a reprint of the article originally published in Finansowanie samorządu terytorialnego i jego zadań a Europejska Karta Samorządu Lokalnego. Local government financing and European Charter of Local Self-Government, J. Gliniecka, A. Drywa, E. Juchniewicz, T. Sowiński (red.), CeDeWu Warszawa 2016

* JUDr. Anna Románová, PhD., Faculty of Law, Pavol Jozef Šafárik University in Košice

* PhD. Ing. Karolína Červená, Faculty of Law, Pavol Jozef Šafárik University in Košice
} 
government are insufficient and systematic changes need to be made. Especially the methods of analysis, synthesis, comparison and historical methods will be applied.

\section{Introduction}

The Constitutional Act no. 460/1992 Coll. the Constitution of Slovak Republic (hereinafter only "Constitution") stipulates in art. 64 that the basis of local self-government is a municipality and that local self-government is created by municipalities and higher territorial units (hereinafter only "HTU"). Among the most important issues regarding the life of local self-government, it sets forth also the issue of their funding. Art. 65 par. 2 declares that municipalities and HTUs shall fund their needs predominantly with the use of their own revenues, and subsequently from state grants. Following this, the Act no. 369/1990 Coll. on municipalities (hereinafter only "Act on Municipalities") confirms this principle in its art. 7 and sets further fort also other resources, such as repayable funding sources, extra-budgetary cash funds or funds associated with other municipalities, HTUs, and natural or legal persons. The Act no. 583/2004 Coll. on fiscal rules of local self-government and on change and amendment of certain laws (hereinafter only "Act on Fiscal Rules") sets forth that revenues of municipalities' budgets are two tier - own resources and other resources ${ }^{2}$. Own resources are created by revenues of local taxes and charges, non-tax revenues from the ownership and transfer of ownership of municipal property and activities of the municipality and its budgetary organizations, interest and other revenues from the funds of the municipality, sanctions for violations of financial discipline imposed by the municipality, donations and revenues from voluntary collections to the municipality, the share of the taxes administered by the state, other revenues on condition that a special law provides so expressly. The others are subsidies from the state budget covering the costs of transferred performance of state administration and subsidies from state funds, additional subsidies from the state budget, purpose-built subsidies from the HTU or from the budget of another municipality to carry out contracts under special laws (e.g. cooperation between municipalities), funds from the European Union and other foreign funds granted for a specific purpose, and other revenues. The municipality is also allowed to use extra-budgetary monetary funds, funds obtained from own

\footnotetext{
${ }^{2}$ Art. 3 par. 1 - 3 of the Act on Fiscal Rules.
} 
business activities, refundable sources of financing, and joint financial resources. The difference consist in the fact that own resources (except for donations for a designated purposes) may be used by a municipality according to its will and needs and the others have to be used only for specified purpose ${ }^{3}$. This structure shows that local self-government has financial relationships to three main groups of persons, i.e. the state/EU and its budget (shared taxes, subsides), other municipalities and HTUs (subsidies, joint resources) and the third one being other natural and legal persons (mainly taxpayers, banks and other financial institutions, business partners, tenants, buyers of municipal property, donators, etc.).

Following the Constitution and the actual goal of fiscal decentralisation, i.e. to create an independent self-government that is capable of funding its needs and execute its policy by own resources, it is obvious that the funds obtained within the own resources should prevail. Even within the above defined group of own resources as set by the Act on Fiscal Rules, we can clearly identify that many of the above resource (e.g. shared taxes) should not be declared to be own resource, since this source depends on the personal income tax and is divided among municipalities and HTUs in the amounts set by the law upon decision of the state, not the local self-government. This means that we have to distinguish the own resources in terms of the mentioned statute and actual own resources of local self-government as those acquired by local selfgovernment itself and which may be called as genuine local resources of funding. The phenomenon we have been observing since the creation of independent Slovak Republic is the lack of ability of municipalities to acquire true own resources for funding of their needs. In this paper, we will analyze the most relevant groups of municipal financial resources and their budgetary effect (also in the view of recent changes and amendments of regulation) and present most important proposals for future development of funding of local self-government.

\section{Most significant financial resources}

As we already mentioned, local revenues can be classified by using two main criteria, i.e. (a) own resources and resources gained from other sources which may also be designated as local revenues and other revenues; (b) tax and nontax revenues; and (c) reimbursable and non-reimbursable. The sources of tax

\footnotetext{
${ }^{3}$ The resources of HTUs are analogical, except for the local taxes.
} 
revenues are created by local taxes, local charges, and shared taxes while main non-tax revenues are grants and transfers from state budget and revenues gained from disposal with municipal property. For the purposes of this article, we will focus only on the revenue sources of municipalities and do not consider those of HTUs.

A) Shared taxes. Act no. 564/2004 Coll. on budgetary determination of income tax revenue for local self-governments and amending certain laws is the basis of sharing the revenue of personal income tax (excluding withholding taxes) as a state tax among municipalities and HTUs. For current budgetary year, i.e. 2016, the revenue from the income tax to be transferred ${ }^{4}$ to municipal budgets is in the amount of $70.0 \%$ and to budgets of HTUs in the amount of $30.0 \%$. In comparison to the previous year, the amount has been raised from $68.5 \%$ for the municipalities and from $29.2 \%$ for the HTUs. The sums are the distributed to particular municipalities and HTUs pursuant to specific criteria defined by the Government regulation no. 668/2004 Coll. on distribution of personal income tax revenue to local self-government (comprising data on number and structure of residents, area, and other coefficients).

B) Subsidies. Subsidies granted to municipalities are three tier: (a) subsidies from the state budget covering the costs of transferred performance of state administration and subsidies from state funds; (b) additional subsidies from the state budget (for specific purposes, e.g. protection of cultural heritage); (c) purpose-built subsidies from the HTU or from the budget of another municipality to carry out contracts under special laws (e.g. cooperation between municipalities ${ }^{5}$ ). Subsidies from the state budget for the purpose of covering local state administration are granted following the details of the state budget for particular budget year and are granted from budget chapters of particular ministry, e.g. ministry of the interior: regarding operating of the registry offices, reporting of residence of citizens and operating registry of inhabitants of the Slovak Republic, the elections, funding of regional education, etc.; ministry of transport, construction and regional development:

\footnotetext{
4 Which meant e.g. for the year 2014 EUR 1727060000 . Available at the Internet: file:///C:/Users/AK/Downloads/prevod_vynosu_dane_z_prijmov_FO_uzemnej_samosprave_za_ro k_2014.pdf.

${ }^{5}$ For details see: KICOVÁ, A., ŠTRKOLEC, M. Vzjomné finančno-právne vztahy jednotiek územnej.

In: Finanse samorzadu terytorialnego. Random: Wyzsza Szkola Handlowa, 2012. ISBN 9788362491247. pp. 381-391.
} 
taskes of specialised building office, etc.. As regards other purpose-built subsidies, these cover usually issues of housing development, support of territorial development of cities and municipalities, funding individual needs of municipalities, protection and restoration of cultural heritage, regional development, or special tasks such as protection and maintenance of the war graves. The use of subsidies must comply with the purpose for which they were granted and is subject to settlement with the state budget. Unused funds or those used in breach of purpose or other conditions upon which the subsidy was granted must be returned to the provider of subsidy. Municipalities may, under art. 7 para. 2 of the Act on Fiscal Rules, provide grants to another municipality or HTU if they secure certain tasks for the municipality or for assistance in liquidation of consequences of natural disasters, accidents or other similar events in their area. Likewise, HTU may, under art. 8 para. 4 of the Act on Fiscal Rules, provide grants to municipalities on its territory as for participation in the funding of common tasks in order to develop the area of HTU and also to other municipalities or HTUs, if it is to provide assistance in liquidation of consequences of natural disasters, accidents or other similar events in their area. The Act on Municipalities provides municipalities with a possibility to fund their tasks by the resources associated with other municipalities, HTUs or with other natural and legal persons. Municipalities may establish a joint extra-budgetary cash funds for funding of the tasks common to more municipalities or for any other reason. Most common reasons are joint exercise of responsibilities in the area of technical infrastructure, the environment, economic development, administration, applying for grants from the European funds for development projects, development of culture, tourism, sport, etc. Administration of such a fund is then performed by a board established by the founding municipalities according to mutually agreed rules.

C) Local taxes. As regards local taxes, these are regulated and were introduced by the act of 23 September 2004 no. 582/2004 Coll. on local taxes and local charge for municipal waste and minor construction waste (hereinafter only "Act on Local Taxes") abolishing the former regulation of act no. 317/1992 Coll. on real property tax, act no. 544/1990 Coll. on local charges and act no. 87/1994 Coll. on road tax. The Act on Local Taxes introduced as local taxes: real property tax, dog tax, tax on use of public areas, accommodation tax, vending machines tax, non-winning gaming machines tax, tax on use of public areas, tax on enter and stay of motor vehicles in historical parts of towns, nuclear facility tax (as taxes administered by municipalities), and 
motor vehicle tax (the only tax administered by HTUs). It actually adopted the former regulation of local charges, property tax, and road tax set by the mentioned statutes, naturally with certain adjustments and with one difference, which was change of character of the taxes. Formerly, the mentioned taxes used to be state taxes but their beneficiary was local selfgovernment. The real property tax was administered by municipalities. Actual imposition of tax was enacted by the mentioned statute and the municipalities were entitled to grant reliefs through their generally binding regulations, though. Regulation itself was significantly similar to the current one ${ }^{6}$ comprising the tax on lands, tax on structures and tax on flats and nonresidential premises. Currently, i.e. since 1 January 2015, the tax on motor vehicles is regulated in a separate statute - act no. 361/2014 Coll. on motor vehicles tax and on change and amendment of certain laws and again as a state tax (hereinafter only "Motor Vehicles Tax").

Local taxes are fully administered by local self-government - municipalities, who are also their beneficiaries. The taxes are imposed by municipalities themselves by means of generally binding regulations (hereinafter only "GBR"). Within these, municipalities are allowed to adjust tax rates, value of building lands, floor surcharge, additional reliefs, instalments, reporting duties \& data to be reported to tax administrator, etc., which enables them to regulate the local taxation according to their local needs. Among local taxes, the most important own tax resource is the real property tax. Property tax is three tier and is levied on (a) lands, (b) buildings, and (c) flats and nonresidential premises. The division among these separate objects is necessary due to lack of application of principle of "superficies solo cedit" in Slovak legal order which results into situations that constructions built on particular plot of land and that plot may be owned by different persons. The tax is predominantly based on the area of property and the use of variety of tax rates relating to differences between types of properties, the purpose of their use and location, which actually serves as adjustment of predominantly areabased type of real property tax. Primary tax rates are stipulated by the Act on Local Taxes and these are: $0.25 \%$ per annum regarding the land tax, 0.033 EUR per each commenced square meter of the built-up area per annum regarding the tax on constructions, and 0.033 EUR per each commenced

\footnotetext{
${ }^{6}$ With slight differences, though, e.g. the basic statutory tax rates were multiplied by coefficient (1.0 to 4.0) according to size of municipality based on the number of inhabitants and administrative importance of particular town ( 7 levels) and separately for the capital city of Bratislava (coefficient 4.5) (see more e.g. art. 6 par. 4 of the act no. 317/1992 Coll.).
} 
square meter of the flat area per annum regarding the flats/non-residential premises tax. Municipalities may set different tax rates in the GBR, application of which is a common practice. Moreover, they are allowed to determine different rates for different types of lands, constructions, flats, and non-residential premises and to take into consideration also the purpose of their use and the location - e.g. in relation to the city centre, cadastral areas, other zones, or otherwise ${ }^{7}$. This diversification of tax rates (together with establishment of a floor surcharge - for multi-storey buildings) can be fully adjusted to local circumstances and used as a tool of local tax policy of each municipality since the Act on Local Taxes gives the municipalities full powers to determine "different tax rates within the area of municipality or parts of it". Since the adoption of the Act on Local Taxes, when municipalities had no limitation regarding the mentioned power of determination of tax rates, the legislator has adopted several amendments to the Act on Local Taxes to limit this power. Currently, the mentioned differently determined rates shall meet two tier limits: Firstly, the limit regarding determination of zones, i.e. individual parts of area of municipality where different tax rates are to be applicable, is stipulated by the Act on Local Taxes in art. 17a. This states that individual part of municipality is a geographically compact part of municipality comprising minimum of $5 \%$ of property tax taxpayers of the municipality and is established within GBR of the municipality. Individual part of the municipality may be formed by a street, neighbouring streets or neighbouring plots of land. Secondly, the municipalities became limited as regards the height of tax rates as follows: (i) highest rates stated in the GBR must not exceed the basic statutory rate more than 5 times in case of arable land, hop gardens, vineyards, orchards, permanent grassland; (ii) highest rates stated in the GBR must not exceed the basic statutory rate more than 10 times in case of forest lands with economic woods, ponds with fish farming and other economic used water areas; (iii) the rate regarding the land tax on lands functionally connected to nuclear facility must not exceed the rate stated by the Act more than 100 times; (iv) highest rates stated in the GBR must not exceed the lowest rates stated in the same regulation more than 5 times as to the land tax on other types of lands and 10 times as to the constructions tax, tax on flats and non-residential premises. There has been quite a challenging discussion regarding the actual power of municipality to set the tax rate at discretion, within the statutory limits, though. The Constitutional Court of

\footnotetext{
${ }^{7}$ In larger towns, it is standard to set 2-4 zones usually based on traditional division to city centre, wider centre and suburbs, but it depends on each municipality what kind of division, if any, chooses.
} 
Slovak Republic has decided ${ }^{8}$ on the case in which the group of parliament representatives challenged the power of a municipality to set the tax rates by GBR, i.e. a bylaw, even if it is delegated by the statute to do so. The complaint has been rejected accenting the constitutional principle of imposition of taxes set by art. 59 of the Constitution ${ }^{9}$ and autonomous powers of municipality performed in line with the Act on Local Taxes and other statutes, nevertheless, there were numerous different opinions published within the reasoning of the finding starting a vivid discussion on the actual meaning of constitutional "on the basis of act".

The rest of the local taxes are rather of less importance as regards the effect on budget of municipalities.

D) Local charges. As regards local charges, Slovak legislation recognises two of them, being the first, the local charge for municipal waste and small construction waste (hereinafter only "charge for municipal waste") and the second, the local charge for development (hereinafter only "charge for development"). The charge for municipal waste is regulated by the Act on Local Taxes and until adoption of the charge for development, it used to be the only local charge applicable. The charge for development as a new tool of local funding is regulated by the act no. 447/2015 Coll. on local charge for development and on amendment of certain laws which was adopted on 20 November 2015 and will be effective from 1 November 2016.

Currently, the charge for municipal waste is paid for municipal waste and minor construction waste arising in the territory of municipality, except for electronic equipment, batteries and accumulators formerly used by natural persons, and biodegradable kitchen and restaurant waste. With effect from 1 July $2016^{10}$, this charged will be paid for management of unsorted municipal waste; management of biodegradable municipal waste; separate collection of municipal waste components not covered by the producer's extended responsibility; costs caused by inconsistent sorting of separately collected fractions of municipal waste covered by producer's extended responsibility; and costs exceeding the usual amount of costs pursuant to caused by disobedience of measures ordered to achieve a more efficient functioning of

\footnotetext{
${ }^{8}$ Finding of the Constitutional Court of Slovak Republic of 22 January 2013, case PL. ÚS 5/2012.

${ }^{9}$ It stipulates that taxes may be imposed by a statute or on the basis of a statute.

${ }^{10}$ Amendment was made by act no. 79/2015 Coll. on wastes and on change and amendment of certain laws.
} 
separate collection of waste ${ }^{11}$, which means broadening of the scope of the charge. The rate is (a) from EUR 0.0033 to 0.0531 per one liter of municipal waste and minor construction waste, or from EUR 0.0066 to 0.1659 per one kilogram of municipal waste and minor construction waste; (b) from EUR 0.0066 to 0.1095 per person per calendar day; (c) from EUR 0.015 to 0.078 per kilogram of minor construction waste free of pollutants. The mechanism of computing the actual amount of the charge depends on whether the municipality uses the collection based on amount of waste or a flat collection - per person and length of the time that person is considered as the payer of the charge (residency in the municipality or usage of a property within municipality).

The charge for development will be levied upon a construction on land ${ }^{12}$ within the territory of municipality for which a valid building permission is issued. The rates can be stipulated by the municipality's GBO within the range from EUR 10 to 35 and different categories of constructions can be charged with various rates. The base of the charge is the area of aboveground part of floor area of the construction which is, in this specific case, comprising the floor area of all aboveground rooms, not only one specific aboveground level of construction as such. The Revenue from the charge for development can only be used for specific purposes, i.e. to cover capital expenditures related to constructions (including the settlement of land) to be used as childcare facilities; facilities providing social, sporting and cultural services; social housing; school equipment and devices for the practical training; medical equipment; publicly accessible park or adjustment of public green; local roads, parking areas and technical infrastructure.

\section{Future proposals \& Conclusions}

Considering the exact "numbers" regarding the above mentioned revenues, in 2014, transfer of shared taxes - PIT to the municipalities represented EUR 1301088000 , grants and transfers (largely to cover performance of

\footnotetext{
${ }^{11}$ Pursuant to art. 59 par. 7 and 8 of act no. 79/2015 Coll. on wastes and on change and amendment of certain laws.

${ }^{12}$ Except for minor constructions, extensions and outbuildings up to 25 square meters of floor area, emergency construction Works, family houses with a floor area up to 150 square meters, constructions used for social housing or childcare, built-in garage and parking spaces within an existing building, medical facilities, serving to kindergartens or schools, social service facilities, practice of religion, protection of the state, museums, galleries, libraries and cultural centres.
} 
transferred state administration) of EUR 1198298 000, non-tax revenues amounted to EUR 634656000 , local taxes revenues accounted for EUR 496622000 (from which EUR 320453000 stands for real property tax and the rest comprises the other local taxes and, mainly, local charge for municipal waste), and EUR 398467000 was created by other income (loans, transfer of funds from other monetary funds, transfer of funds from previous budgetary year, etc. $)^{13}$. Looking at the ratio of particular municipality's budgetary revenues, it clearly shows that genuine own, i.e. local, sources of funding are definitely insufficient. Beside search for better tax revenues, also the group of non-tax revenues should be considered as an issue to improve and develop. This group (comprising revenues from own business activities, use of municipal movable and immovable property and its disposal, administrative and other fees and charges for specific services) is definitely a sphere where abilities and creativity of particular municipality can be shown. As we see, the revenue from local taxes and charges is similar to that gained from non-tax revenue, which is a significant amount.

We mentioned above two major amendments to legislation that are already valid and will take effect within the current year, i.e. the new charge on development and amendment of charge on municipal waste. The background or the main reason of the change is obvious and it is nothing else than fiscal interest, nevertheless, it is the matter of future whether it meets the intended goal. Ever since the introduction of fiscal decentralisation, local selfgovernment keeps fighting with the inadequate funding of their needs as regards covering the independent functioning and securing their own selfgoverning tasks. This struggle for balance in relation between competences and resources definitely needs a more efficient solution then a sole almost 20years lasting debate on how to solve the problem. Beside the changes regarding the regulation of the local charges, a strong issue is a fundamental change of system of taxation of real property. In recent years, the Government of Slovak Republic (perhaps also due to pressure of the $\mathrm{EU}^{14}$ ) has been presenting an idea of fundamental reform of real property tax as regards the base of taxation. The eventual proposal should move from "area based" system to "ad valorem" system. National programme of reforms in Slovak

\footnotetext{
${ }^{13}$ Data acquired from: Ministry of Finance of Slovak Republic: Budget of public administration for years 2016 - 2018. Available at the Internet: http://www.finance.gov.sk/Default.aspx?CatID=10249.

${ }^{14}$ See Council Recommendation of 8 July 2014 on Slovakia's 2014 national reform programme and delivering a Council opinion on the Stability Programme of Slovakia, 2014 (2014/C 247/23).
} 
Republic 2014 clearly declares this ${ }^{15}$, nevertheless, there is no draft legislation available yet and, comparing the above with the wording of National programme of reforms in Slovak Republic $2013^{16}$, a slight moderation of strict approach or even some stagnation is visible. A question arises, what is the actual aim of the potential reform. If the revenue is the most significant factor, then we do not really understand discrepancies between deemed importance of increasing the revenue and above discussed continuous limitation of powers of municipalities to determine tax rates according to their need. In favour of this inconsistency speaks also unofficial information on only a slight increase of presumed revenue that should be achieved by the change of current system. If the most important idea is to be the equity, then we do hesitate on ability of a new system to achieve it (mainly due to incomplexity of database and state of development of real estate market). From the already published documents of the Government, it seems that the reform should firstly aim at residential properties, which regarding both mentioned possible aims, might not be the best start. Much more reasonable might be considering the properties of administrative and business purposes as first (which would be of a much higher value). In our view, an improvement of state of the art might be achieved in an acceptable way by further adjustment of current regulation by other coefficients along with the existing type of property, purpose of use, and location. An important issue that evidently has been underestimated is tackling first the most urgent application problem that real property tax is struggling with, being low efficiency of tax administration. If we consider the costs and effort that will have to be made to implement the

\footnotetext{
${ }^{15}$ Taxes on real property in Slovak Republic as compared to other OECD or EU countries create a less important part of revenues of local self-government. The system in its current configuration (the tax rate in EURO on the basis of size of habitable area) is less efficient and less fair because the tax base does not reflect the real value of real property (defined by size of settlement, location of property, its age, accessories and other parameters) but only its area. This, in turn, leads to a different effective tax burden on the property (as a ratio between the tax paid and the price of the immovable property) and regressive effects of the system. As far as tax equity is concerned, an optimum solution is to configure the system in such a way that the tax base will be linked to an estimated market value of the particular real estate. This would ensure that tax base would be changing along with the market value of the property and the effective taxation would remain constant at an unchanged rate. The Ministry of Finance is currently examining possible alternatives to introduce a property tax system based on the market value of real estate properties. First steps in implementation of the new system will be taken after 2015. (National programme of reforms in Slovak Republic 2014, p. 34).

${ }^{16}$... Exact proposals will be finalised in the course of 2013 and a new system introduced by 2015, at the latest (For more see National programme of reforms in Slovak Republic 2014, p. 34).
} 
intended reform and then we finally arrive at the point of collection of taxes, where the "stumbling block" lies, what would the point of the reform be?

Therefore, in our view, as a true challenge the issue of inefficiency of tax administration, particularly tax collection, can be depicted. This problem is however, quite illogical, since a real property cannot "move" and, after all, seizure and sale of the property belongs to standard means of tax enforcement proceedings. Administration of local taxes comprises a complex application problem. Despite dual enforcement procedures available (via the act no. 563/2009 Coll. on administration of taxes (code of tax procedure) and on change and amendment of certain laws and via civil bailiffs), neither of them is satisfactory. The former requires qualified personnel to be able to manage the procedure duly; the second one can be costly in cases of uncollectable debts ${ }^{17}$. In both cases, seizure and sale of real property of a tax debtor is rarely performed due to unwillingness of tax administrator to undergo the demanding procedure. The lists of debtors published on websites of municipalities had certain benefits, large amount of tax arrears, however, keep being uncollected ${ }^{18}$. In many cases, due tax simply is not being collected and enforced. Self-governing powers does not bring only positives. In this respect, we consider position of each municipality as administrator of local taxes to be a systematic error since majority of municipalities is incapable of proper administration of taxes.

Therefore, we can conclude that current system of functioning of local selfgovernment has two main problems, first being the lack of revenue resources and their richness and the second is inefficiency of administrative capabilities of local self-government. From our view, unfortunately, both of them need a systematic reform.

\footnotetext{
${ }^{17}$ For more see ROMÁNOVÁ, A. Miestne dane ako zdroj príjmov rozpočtov územnej samosprávy. In: Verejné financie Slovenskej republiky - vybrané aspekty a tendencie vývoja. Košice: P. J. Šafárik University in Košice, 2011. p. 63-68.

${ }^{18}$ For example in Košice, on 31 December 2014, there were 651 tax debtors with total amount of arrears of EUR 2025333.66 (source: List of tax debtors. Available at: http://esamosprava.kosice.sk/Zverejnenie/Nedoplatky.aspx).
} 